\title{
PENGARUH PEMANFAATAN MEDIA SOFTWARE PhET (PHYSICS EDUCATION TECHNOLOGY) SEBAGAI MEDIA PEMBELAJARAN TERHADAP PRESTASI BELAJAR FISIKA SISWA SMA
}

\author{
M. Abdurrahman Sunni. \\ STMIK Mataram \\ man.sunni@gmail.com
}

\begin{abstract}
Abstrak: Penelitian ini adalah penelitian eksperimen yang bertujuan untuk mengetahui pengaruh pemanfaatan software PhET sebagai media pembelajaran terhadap prestasi belajar fisika siswa. Penelitian ini merupakan penelitian eksperimen kuasi. Populasi penelitian ini adalah seluruh kelas X SMA Negeri 8 Mataram. Pengambilan sampel digunakan dengan teknik cluster random sampling sehingga diperoleh kelas X Asta 3 sebagai kelas eksperimen, sedangkan kelas kontrol adalah kelas X Asta 4. Data hasil prestasi belajar dianalisis dengan uji-t pihak kanan dan diperoleh data untuk ranah kognitif thitung $=4,05$ dan tabel $=1,67$; sedangkan untuk ranah psikomotor $t_{\text {hitung }}=2,28$ dan tabel $=1,67$ pada $\mathrm{dk}=51$ dengan taraf signifikan $5 \%$. Hasil penelitian menunjukkan thitung $>$ ttabel maka $\mathrm{H}_{0}$ ditolak dan $\mathrm{H}_{a}$ diterima yang menunjukkan bahwa pemanfaatan software $\mathrm{PhET}$ sebagai media pembelajaran berpengaruh positif terhadap prestasi belajar fisika siswa kelas X SMA Negeri 8 Mataram.
\end{abstract}

Kata Kunci : Media Software PhET, Prestasi Belajar Fisika.

\section{Latar Belakang}

Pelajaran fisika merupakan pelajaran yang harus dipahami konsepnya bukan hanya dihafalkan. Siswa akan senang belajar fisika jika telah memahami keindahannya dan atau manfaatnya. Ketika siswa sudah mulai tertarik, mereka akan bisa lebih mudah dalam menguasai fisika. Selain itu, jika materi yang sedang dibahas telah pernah dialami oleh siswa mungkin siswa akan dapat merekonstruksinya kembali menjadi pemahaman yang lebih baik. Oleh sebab itu, siswa diharapkan berusaha untuk memahami konsep yang mendasari suatu materi.

Mengingat pentingnya pemahaman tentang suatu konsep dalam pelajaran fisika, maka dibutuhkan media pembelajaran yang menyenangkan dan efektif. Pemakaian media pembelajaran dalam proses belajar mengajar dapat membangkitkan keinginan, minat yang baru, membangkitkan motivasi dan rangsangan kegiatan pembelajaran bahkan membawa pengaruh-pengaruh psikologis terhadap siswa. Media ini diharapkan dapat membantu efektifitas proses pembelajaran serta penyampaian pesan dan isi pelajaran sehingga siswa dapat meningkatkan pemahamannya tentang konsep-konsep fisika yang masih bersifat asbtrak agar mudah dipahami dan diaplikasikan dalam kehidupan sehari-sehari (Pusporini, 2012). Hal ini memungkinkan tercapainya tujuan pembelajaran, yang pada akhirnya dapat meningkatkan ketuntasan belajar.

Salah satu solusi alternatif media yang dapat digunakan untuk memudahkan pemahaman tentang konsep-konsep fisika yang bersifat abstrak adalah dengan menggunakan media pembelajaran software PhET. Software PhET merupakan program berbasis Java yang menyenangkan dan interaktif. Tujuan pembelajaran fisika di kelas dengan menggunakan software PhET yaitu menanamkan konsep fisika baik yang bersifat abstrak maupun konkret. Pembelajaran berbasis media komputer dapat meningkatkan nilai para siswa (konsep), sikap mereka terhadap belajar dan evaluasi dari pengalaman belajar mereka
(Prihatiningtyas, 2013). Media pembelajaran menggunakan software PhET yang berbasiskan komputer dapat dijadikan media alternatif dalam meningkatkan kemampuan siswa.

Media pembelajaran yang tepat akan membuat pembelajaran lebih menarik dan meningkatkan minat siswa untuk belajar serta diharapkan prestasi belajarnya pun meningkat (Pusporini, 2012). Media pembelajaran mempunyai arti penting pada proses pembelajaran. Kehadiran media pembelajaran dapat membawa pengaruh positif terhadap siswa. Salah satu media pembelajaran yang menarik dan dapat memotivasi mahasiswa adalah media software PhET (Physics Education Technology).

Media Software PhET merupakan simulasi yang dibuat oleh Universitas Colorado yang berisi simulasi pembelajaran fisika untuk kepentingan pengajaran di kelas atau belajar individu (Prihatiningtyas, 2013). Kelebihan dari simulasi PhET yakni dapat melakukan percobaan secara ideal, yang tidak dapat dilakukan dengan menggunakan alat yang sesungguhnya. Dipilihnya simulasi PhET karena simulasi ini bersifat interaktif dan menarik dikemas dalam bentuk seperti permainan. Simulasi-simulasi PhET terdiri dari objekobjek yang tidak terlihat mata di dunia nyata, seperti atom, elektron, foton, dan medan listrik. Dengan animasi yang disajikan para siswa dapat menyelidiki sebab dan akibat pada fenomena yang disajikan. Simulasi PhET menekankan hubungan antara fenomena kehidupan nyata dengan ilmu yang mendasari, mendukung pendekatan interaktif dan konstruktivis, memberikan umpan balik, dan menyediakan tempat kerja kreatif (Finkelstein, 2006).

Salah satu tujuan pembelajaran fisika adalah menguasai konsep dasar fisika (Depdiknas, 2006). Penguasaan konsep dapat membantu siswa meningkatkan prestasi belajar. Penguasaan konsep akan dimiliki siswa jika siswa terlibat secara langsung dalam proses pembelajaran. Keterlibatan siswa dalam aktivitas pembelajaran akan berdampak positif pada prestasi belajar siswa (Arends, 2012). Dengan demikian, perlu digunakan media yang menarik bagi 
siswa dalam belajar fisika. Penggunaan media software PhET ini akan membantu siswa dalam mengembangkan kemampuan berpikir tingkat tinggi.

Berdasarkan uraian di atas maka perlu dilakukan penelitian dengan judul Pengaruh Pemanfaatan Media Software PhET terhadap Prestasi Belajar Fisika Siswa SMA. Tujuan penelitian ini adalah untuk mengetahui apakah media software PhET sebagai media pembelajaran dapat berpengaruh positif terhadap prestasi belajar fisika siswa kelas $X$ SMA. Pembelajaran yang menggunakan media software PhET diharapkan dapat menciptakan suasana pembelajaran yang menarik, membuat siswa lebih aktif, dan meningkatkan motivasi belajar siswa sehingga dapat dapat meningkatkan prestasi belajar fisika siswa.

\section{Kajian Pustaka}

Sanaky (2009) menyatakan bahwa media pembelajaran adalah sebuah alat yang berfungsi dan digunakan untuk menyampaikan pesan pembelajaran. Pembelajaran adalah proses komunikasi antara pembelajar, pengajar dan bahan ajar. Dapat dikatakan bahwa, bentuk komunikasi tidak akan berjalan tanpa bantuan sarana untuk menyampaikan pesan. Bentukbentuk stimulus dapat dipergunakan sebagai media, diantaranya adalah hubungan atau interaksi manusia, realitas, gambar bergerak atau tidak, tulisan dan suara yang direkam.

Media pembelajaran banyak sekali jenis dan macamnya, mulai dari yang paling sederhana dan murah hingga yang paling canggih dan mahal harganya. Ada media yang dapat dibuat oleh guru sendiri, diproduksi oleh pabrik, sudah tersedia di lingkungan yang langsung dapat kita manfaatkan, dan ada pula yang secara khusus dirancang untuk keperluan pembelajaran. Arsyad (2011) menjelaskan manfaat semua media pembelajaran diantaranya: (1) Memperjelas penyajian pesan yang dapat meningkatkan hasil belajar. (2) Meningkatkan dan mengarahkan perhatian anak sehingga dapat menimbulkan motivasi belajar, interaksi yang lebih langsung antara siswa dan lingkungannya, dan kemungkinan siswa untuk belajar sendiri-sendiri sesuai dengan kemampuan yang dimilikinya.(3) Mengatasi keterbatasan indera, ruang dan waktu.(4) Memberi rangsangan yang sama, mempersamakan pengalaman dan menimbulkan persepsi yang sama.

Upaya untuk meningkatkan minat dan motivasi siswa dalam proses pembelajaran masalah dapat dibantu dengan penggunaan teknologi virtual. Fenomena fisika dan konsep-konsepnya yang terkait dengan simulasi serta terkait dengan aplikasi keseharian siswa dapat menambah pengetahuan siswa secara visual dan menstimulus lebih banyak siswa untuk mencapai tingkat penguasaan yang tinggi mengenai konsep ilmu fisika (Tuysuz, 2010:38).

Simulasi komputer memiliki kemampuan untuk dapat memaparkan sesuatu yang rumit atau komplek atau sulit untuk dijelaskan dengan hanya gambar atau kata-kata saja. Dengan kemampuan ini maka simulasi dapat digunakan untuk menjelaskan suatu materi yang secara nyata tidak dapat terlihat oleh mata, dengan cara melakukan visualisasi maka materi yang dijelaskan dapat tergambarkan (Flowers, 2011). Selain itu simulasi sebagai media ilmu pengetahuan dapat dijadikan sebagai perangkat ajar yang siap kapan saja untuk mengajarkan materi yang telah disimulasikan, terutama dengan adanya teknologi interaktif pada saat ini baik melalui perangkat komputer ataupun perangkat elektronik lainnya.

Media simulasi PhET merupakan salah satu media simulasi virtual. Laboratorium virtual memberikan kesempatan untuk melakukan investigasi dan eksperimen tanpa mengaitkan dengan objek percobaan. Laboratorium virtual mampu menyederhanakan percobaan berdasarkan tingkat keahlian pengguna (Karagoz, 2010). Pelaksanaan laboratorium virtual dapat meningkatkan pemahaman materi siswa, mengajarkan keterampilan berpikir kritis, dan meningkatkan keterampilan pemecahan masalah Laboratorium virtual juga efektif dalam meningkatkan motivasi siswa (Tuysuz, 2010).

Media simulasi PhET merupakan simulasi virtual yang dibuat oleh Universitas Colorado Amerika yang berisi simulasi pembelajaran fisika untuk kepentingan pengajaran di kelas atau belajar individu. Simulasi PhET menekankan hubungan antara fenomena kehidupan nyata dengan ilmu yang mendasari, mendukung pendekatan interaktif dan konstruktivis, memberikan umpan balik, dan menyediakan tempat kerja kreatif (Finkelstein, 2006:119). Simulasi yang disediakan PhET sangat interaktif, mengajak siswa untuk belajar dengan cara mengeksplorasi secara langsung. Software PhET ini membuat suatu animasi fisika yang abstrak atau tidak dapat dilihat oleh mata telanjang, seperti : atom, electron, foton dan medan magnet. Untuk eksplorasi secara kuantitatif, software PhET ini memiliki alat-alat ukur di dalamnya seperti penggaris, stopwatch, voltmeter dan termometer. Contoh media software PhETditampilkan pada gambar 2.1 berikut.

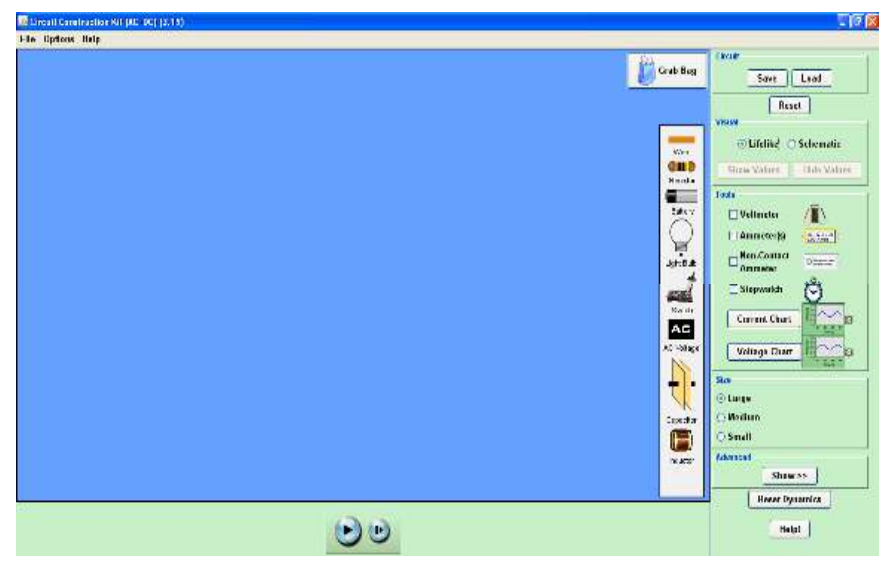

Gambar 2.1: Media Software PhET Listrik Dinamis

Kelebihan dari media simulasi PhET yakni dapat melakukan percobaan secara ideal, yang tidak dapat dilakukan dengan menggunakan alat yang sesungguhnya. Dipilinnya simulasi PhET ini karena simulasi dalam PhET bersifat interaktif dikemas 
dalam bentuk seperti game/permainan. Siswa dapat melakukan interaksi melalui gambar dan kontrol-kontrol intuitif yang di dalamnya memuat klik dan seret (click and drag), saklar geser dan tombol-tombol. Dengan animasi yang disajikan para siswa dapat menyelidiki sebab dan akibat pada fenomena yang disajikan.

Menurut Sugiyono (2010), hipotesis penelitian adalah jawaban sementara yang dinyatakan dalam bentuk pernyataan dan dirumuskan berdasarkan masalah yang diangkat di dalam penelitian. Hipotesis penelitian bersifat sementara karena jawaban hanya didasarkan pada teori yang relevan dan tidak didasarkan pada fakta-fakta empiris yang diperoleh di lapangan melalui pengambilan data. Berdasarkan kajian pustaka dan kerangka berpikir yang dikemukakan peneliti, maka peneliti mengajukan hipotesis:

Ho: Penggunaan media software PhET sebagai media pembelajaran tidak berpengaruh positif terhadap prestasi belajar fisika siswa kelas X SMA Negeri 8 Mataram.

Ha: Penggunaan media software PhET sebagai media pembelajaran dapat berpengaruh positif terhadap prestasi belajar fisika siswa kelas X SMA Negeri 8 Mataram.

\section{METODE PENELITIAN}

Penelitian yang dilakukan merupakan penelitian eksperimen kuasi dengan menggunakan dua kelompok kelas yaitu kelompok kelas eksperimen dan kelompok kelas kontrol. Pretest-Posttest Control Group Design merupakan desain penelitian yang akan digunakan oleh peneliti di dalam penelitian ini.

Tabel 3.1

Desain Penelitian

\begin{tabular}{|c|cc|c|c|c|}
\hline \multirow{2}{*}{ Kelas } & \multirow{2}{*}{ Desain } & \multirow{2}{*}{ Perlakuan } & \multicolumn{2}{|c|}{ Tes } \\
\cline { 4 - 6 } & & & Awal & Akhir \\
\hline Eksperimen & $\mathrm{O}_{1} \mathrm{X}_{2}$ & $\mathrm{Ya}$ & $\mathrm{Ya}$ & $\mathrm{Ya}$ \\
\hline Kontrol & $\mathrm{O}_{3}$ & $\mathrm{O}_{4}$ & Tidak & $\mathrm{Ya}$ & $\mathrm{Ya}$ \\
\hline
\end{tabular}

Dalam desain ini terdapat dua kelompok yang dipilih secara acak, kemudian diberi tes awal. Tes awal bertujuan untuk mengetahui keadaan awal antara kelompok eksperimen dan kelompok kontrol. Hasil tes awal dikatakan baik apabila nilai kelompok eksperimen dan kontrol tidak berbeda secara signifikan.

Kelas eksperimen pertama diberikan perlakuan berupa pembelajaran fisika berbantuan media software $\mathrm{PhET}$, sedangkan kelas kontrol diberikan perlakuan pembelajaran konvensional. Penelitian ini memberikan gambaran tentang perbandingan prestasi belajar fisika dengan berbantuan media software PhET, dan siswa yang belajar dengan pembelajaran konvensional.

Populasi dalam penelitian ini adalah kelas $X$ SMA Negeri 8 Mataram terdiri dari 4 kelas dengan jumlah 160 siswa. Sampel diambil dengan acak dan terpilih kelas X Asta 3 sebagai kelas eksperimen dan kelas X Asta 4 sebagai kelas kontrol.

Instrumen penelitian terdiri dari silabus, RPS, LKS, soal penguasaan konsep fisika. Tes penguasaan konsep siswa menggunakan tes pilihan ganda sebanyak 24 soal yang telah divalidasi oleh dosen ahli, kemudian dilakukan uji coba untuk menentukan validitas dan reliabilitasnya. Soal pilihan ganda ini menggunakan kisi-kisi soal dengan tingkat kognitif mulai dari C1 sampai C6 yang disesuaikan dengan indikator yang hendak dicapai. Soal penguasaan konsep dikembangkan pada materi listrik dinamis.

Analisis data merupakan suatu proses untuk menguji hipotesis penelitian. Analisis data yang digunakan adalah uji-t selisih antara post-test dengan pre-test. Sebelum dilakukan uji hipotesis, terlebih dahulu dilakukan uji prasyarat, yaitu uji normalitas dan uji homogenitas.

\section{HASIL dan PEMBAHASAN}

\section{A. Hasil Penelitian}

Data yang dikumpulkan di dalam penelitian ini disesuaikan dengan keperluan analisis, yakni analisis uji beda (uji-t) prestasi belajar siswa yang diajar menggunakan software PhET pada kelas eksperimen, dengan prestasi belajar siswa yang diajar tanpa menggunakan software PhET pada kelas kontrol. Sehingga objek di dalam penelitian ini adalah prestasi belajar siswa.

Prestasi belajar siswa yang akan dianalisis didapatkan dari hasil tes akhir dengan jumlah soal 25 butir, dengan nilai maksimal ideal $=100$ dan nilai minimal ideal $=0$. Dengan demikian, hasil pengukuran variabel prestasi belajar fisika siswa untuk setiap kelompok dideskripsikan sebagai berikut.

Grafik 4.1

Hasil Pre-Test Kelas Eksperimen dan Kelas Kontrol

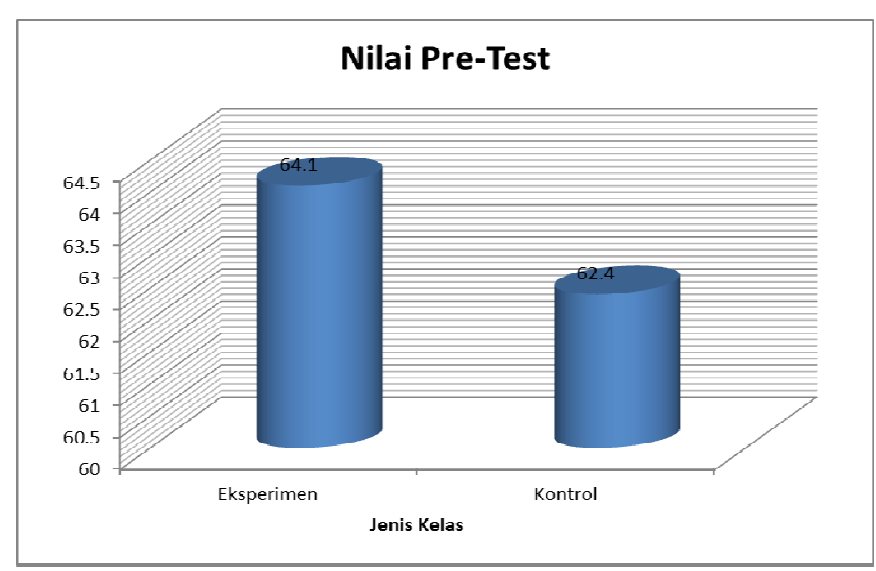

Grafik 4.2

Hasil Post-Test Kelas Eksperimen dan Kelas Kontrol (Kognitif)

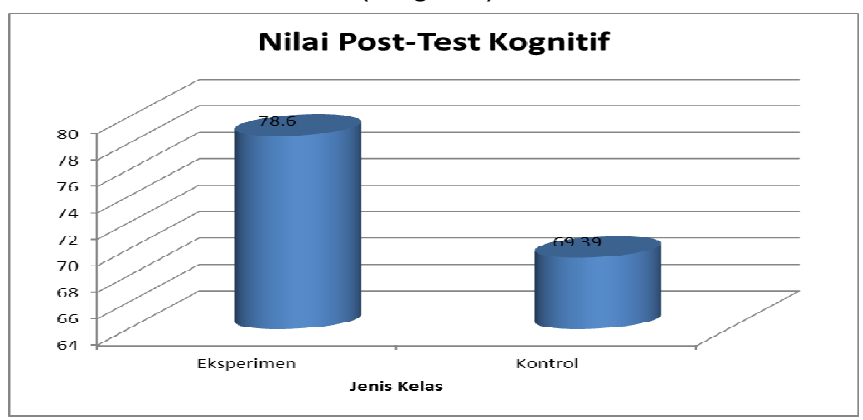


Grafik 4.3

Hasil Post-Test Kelas Eksperimen dan Kelas Kontrol (Psikomotor)

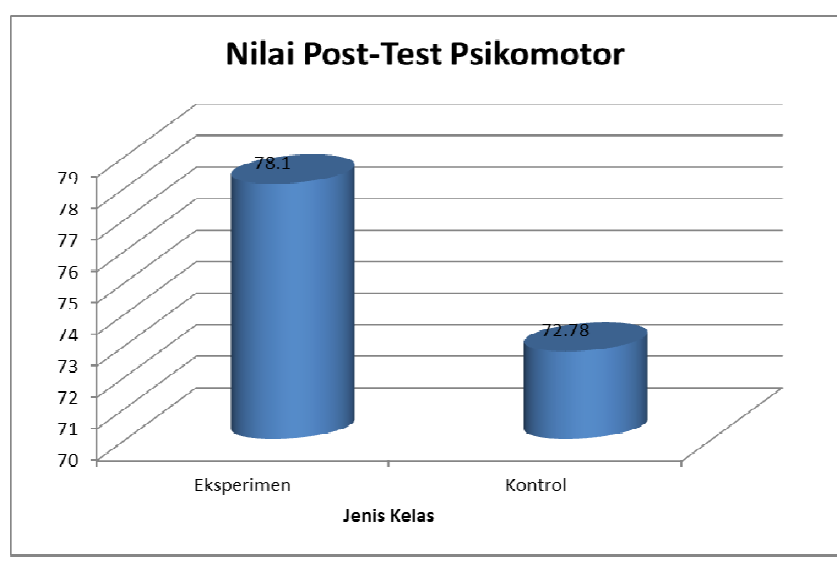

1) Hasil Uji Homogenitas Pre-Test

Uji homogenitas bertujuan untuk mengetahui seragam tidaknya varians sampel-sampel yang diambil dari populasi yang sama. Adapun hasil uji homogenitas dapat dilihat pada tabel berikut.

\section{Tabel 4.1}

Hasil Uji Homogenitas Kelas Eksperimen dan Kelas Kontrol Pre-Test (Kognitif)

\begin{tabular}{|l|c|c|c|c|}
\hline \multicolumn{1}{|c|}{ Kelas } & $\begin{array}{c}\text { Standar } \\
\text { Deviasi } \\
(S)\end{array}$ & $\begin{array}{c}\text { Varians } \\
\left(S^{2}\right)\end{array}$ & F hitung & F tabel \\
\hline Eksperimen & 6,54 & 42,77 & \multirow{2}{*}{1,13} & 1,96 \\
\hline Kontrol & 6,95 & 48,30 & 13 \\
\hline
\end{tabular}

Karena $F_{\text {hitung }}<F_{\text {tabel }}$ maka varians kedua kelompok data adalah homogen.

\section{2) Hasil Uji Normalitas Post-Test (Kognitif)}

a. Data Prestasi Belajar Siswa Kelas Eksperimen Dari hasil pengukuran prestasi belajar siswa pada pelajaran fisika, di kelas ekperimen ranah kognitif diperoleh nilai rata-rata $=78,6$ dan standar deviasi $=$ 6,54. Agar tampak lebih jelas, hasil pengukuran prestasi belajar siswa disajikan pada grafik 4.4 berikut.

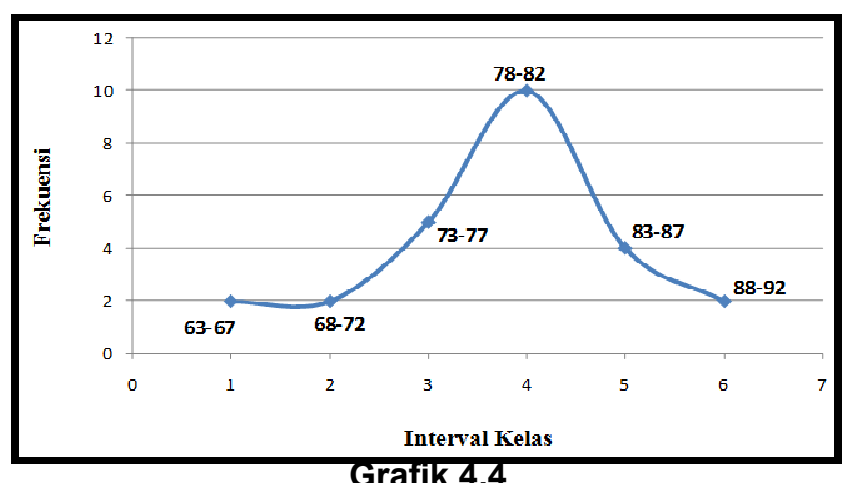

Uji Normalitas Kelas Eksperimen (Kognitif)

Berdasarkan grafik 4.4 prestasi belajar fisika siswa yang mengikuti media software $\mathrm{PhET}$, tampak bahwa frekuensi tertinggi terletak pada rentang 78-82 dan frekuensi terendah terletak pada rentang 63-67, 68-72 dan 88-92.

\section{b. Data Prestasi Belajar Siswa Kelas Kontrol}

Dari hasil pengukuran prestasi belajar siswa pada pelajaran fisika di kelas kontrol, ranah kognitif diperoleh nilai rata-rata $=69,39$ dan standar deviasi $=6,95$. Agar tampak lebih jelas, hasil pengukuran prestasi belajar siswa disajikan pada grafik 4.5 berikut.

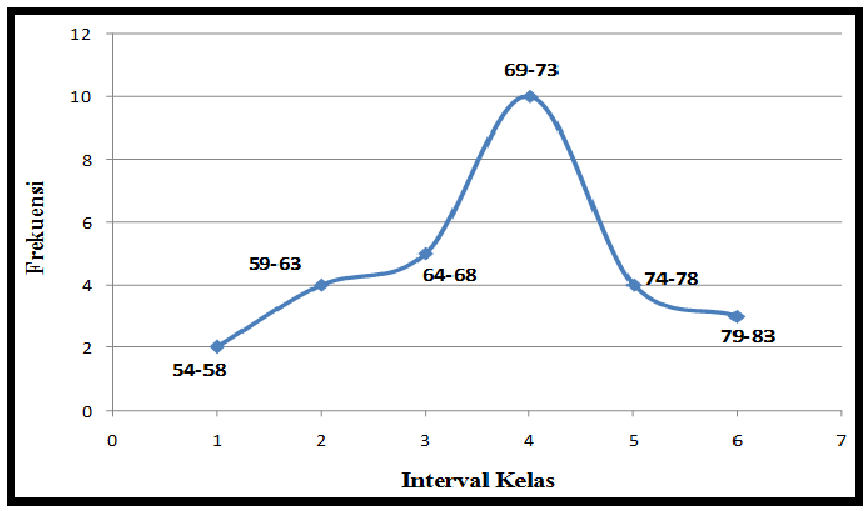

Grafik 4.5

Uji Normalitas Kelas Kontrol (Kognitif)

Berdasarkan grafik 4.5 prestasi belajar fisika siswa yang mengikuti pembelajaran tanpa media software PhET, tampak bahwa frekuensi tertinggi terletak pada rentang 69-73 dan frekuensi terendah terletak pada rentang 54-58.

\section{3) Hasil Uji Normalitas Post-Test (Psikomotor)}

a. Data Prestasi Belajar Siswa Kelas Eksperimen Dari hasil pengukuran prestasi belajar siswa pada pelajaran fisika di kelas eksperimen ranah psikomotor diperoleh nilai rata-rata $=78,10$ dan standar deviasi $=8,30$. Agar tampak lebih jelas, hasil pengukuran prestasi belajar siswa disajikan pada grafik 4.6 berikut.

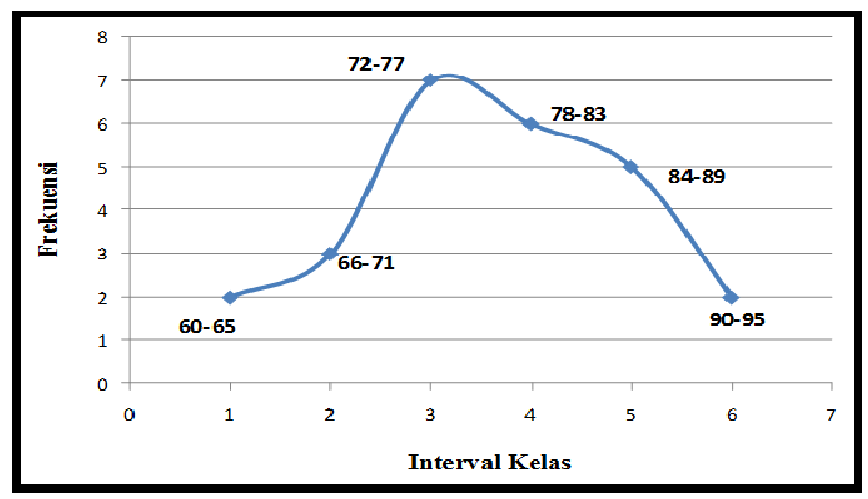

Grafik 4.6

Uji Normalitas Kelas Eksperimen (Psikomotor)

Berdasarkan grafik 4.6 prestasi belajar fisika siswa yang mengikuti media software $\mathrm{PhET}$, tampak bahwa frekuensi tertinggi terletak pada rentang 
frekuensi terendah terletak pada rentang 60-65 dan 9095.

\section{b. Data Prestasi Belajar Siswa Kelas Kontrol}

Dari hasil pengukuran prestasi belajar siswa pada pelajaran fisika di kelas kontrol, ranah psikomotor diperoleh nilai rata-rata $=72,78$ dan standar deviasi $=$ 8,62. Agar tampak lebih jelas, hasil pengukuran prestasi belajar siswa disajikan pada grafik 4.7 berikut.

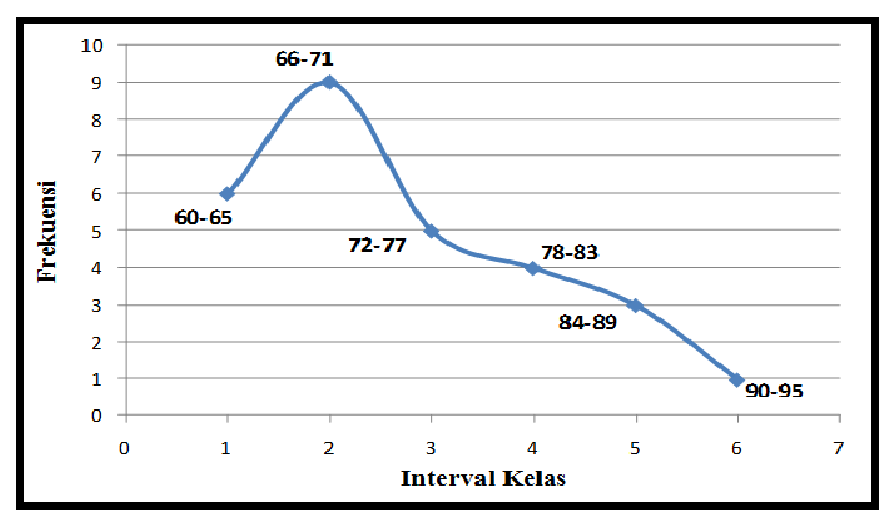

Grafik 4.7

\section{Uji Normalitas Kelas Kontrol (Psikomotor)}

Berdasarkan grafik 4.7 prestasi belajar fisika siswa yang mengikuti pembelajaran tanpa media software $\mathrm{PhET}$, tampak bahwa frekuensi tertinggi terletak pada rentang 66-71 dan frekuensi terendah terletak pada rentang 90-95.

\section{4) Hasil Uji Hipotesis (Kognitif)}

Uji hipotesis dilakukan untuk mengetahui ada tidaknya perbedaan setelah diberi perlakuan antara pre-test dengan post-test untuk kelas eksperimen dan kelas kontrol. Adapun hasil uji hipotesis (pihak kanan) dapat dilihat pada tabel 4.1 berikut.

Tabel 4.1

Hasil Uji Hipotesis Kelas Eksperimen dan Kelas Kontrol (Kognitif)

\begin{tabular}{|c|c|c|c|c|c|}
\hline Kelas & $\begin{array}{c}\text { Jumlah } \\
\text { Siswa } \\
(\mathrm{N})\end{array}$ & $\begin{array}{c}\text { Rata- } \\
\text { Rata } \\
(\bar{X})\end{array}$ & Varians & thitung & ttabel \\
\hline Eksperimen & 25 & 14,64 & 731,76 & 4,05 & 1,67 \\
\hline Kontrol & 28 & 9,25 & 455,25 & 4,05 \\
\hline
\end{tabular}

Hasil uji hipotesis menunjukkan thitung $>t_{\text {tabel }}$ maka Ho ditolak dan Ha diterima.

\section{5) Hasil Uji Hipotesis (Psikomotor)}

Uji hipotesis dilakukan untuk mengetahui ada tidaknya perbedaan setelah diberi perlakuan pada kelas eksperimen dan kelas kontrol. Adapun hasil uji hipotesis (pihak kanan) dapat dilihat pada table 4.2 berikut.

\section{Tabel 4.2}

Hasil Uji Hipotesis Kelas Eksperimen dan Kelas Kontrol (Psikomotor)

\begin{tabular}{|c|c|c|c|c|c|}
\hline Kelas & $\begin{array}{c}\text { Jumlah } \\
\text { Siswa } \\
(N)\end{array}$ & $\begin{array}{c}\text { Rata- } \\
\text { Rata } \\
(\bar{X})\end{array}$ & $\begin{array}{c}\text { Varians } \\
\left(S^{2}\right)\end{array}$ & thitung & tabel \\
\hline Eksperimen & 25 & 78,10 & 68,89 & 2,28 & 1,67 \\
\hline Kontrol & 28 & 72,78 & 74,30 & 2,28 & \\
\hline
\end{tabular}

Hasil uji hipotesis menunjukkan $t_{\text {hitung }}>t_{\text {tabel }}$ maka Ho ditolak dan Ha diterima.

\section{B. Pembahasan}

Pembahasan hasil penelitian yang dijelaskan pada bagian ini berupa hasil analisis deskriptif dan statistik antara variabel bebas yaitu media pembelajaran yang merupakan variabel perlakuan dan variabel terikat yaitu prestasi belajar siswa. Berkenaan dengan hasil penelitian ini, didapatkan bahwa terdapat perbedaan prestasi belajar siswa yang mengikuti pembelajaran dengan media pembelajaran software PhET dengan tanpa menggunakan media software PhET. Pada kelompok siswa yang mengikuti pembelajaran dengan media software PhET didapatkan bahwa prestasi belajar siswa berkategori sangat tinggi. Sedangkan pada kelompok siswa yang mengikut pembelajaran dengan tanpa menggunakan media software PhET berkategori tinggi. Hasil ini kemudian memberikan sebuah pertanyaan mendasar yaitu mengapa siswa yang mengikuti pembelajaran dengan menggunakan media software PhET mencapai prestasi belajar dengan kategori sangat tinggi sedangkan siswa yang mengikuti pembelajaran tanpa menggunakan media software PhET hanya memiliki prestasi dengan kategori tinggi.

Materi yang diajarkan pada penelitian ini adalah muatan dan alat ukur listrik, hukum Ohm, hukum Kirchoff, rangkaian seri dan parallel. Dari hasil pre-test dan post-test untuk kelas eksperimen dan kelas kontrol berdasarkan sub materi yang diajarkan, didapatkan bahwa untuk kelas eksperimen nilai rata-rata tertinggi siswa dengan skala 6 terdapat pada materi hukum Ohm yaitu pada hasil pre-test, nilai rata-ratanya 4,28 dan pada hasil post-test, nilai rata-ratanya 5,48 . Sedangkan nilai rata-rata siswa terendah terdapat pada materi hukum Kirchoff yaitu pada hasil pre-test, nilai rataratanya 3,24 dan pada hasil post-test, nilai rata-ratanya 3,92. Untuk kelas kontrol, materi hukum Ohm merupakan materi termudah, ini dibuktikan dari nilai rata-rata tertinggi siswa, yakni 3,93 pada hasil pre-test dan 5,00 pada hasil post-test. Sedangkan materi hukum Kirchoff merupakan materi tersulit, ini dibuktikan dari nilai rata-rata siswa terendah siswa, yakni 3,29 pada hasil pre-test dan 3,43 pada hasil post-test,

Dari hasil di atas menunjukkan bahwa materi hukum Ohm merupakan materi yang paling mudah dan paling banyak dijawab benar oleh siswa. Ini diperkuat dengan hasil uji instrument yang menunjukkan bahwa materi hukum Ohm memiliki indeks kesukaran rata-rata 0,81 yang termasuk dalam klasifikasi soal mudah. Materi hukum Ohm menjelaskan tentang bagaimana hubungan antara hambatan, tegangan dan kuat arus listrik. Pemahaman siswa diperkuat dengan adanya media software PhET yang memungkinkan siswa membuktikan hukum Ohm. Siswa bisa melihat 
bagaimana hubungan antara kuat arus dengan hambatan ketika tegangan konstan, jika hambatan lampu diperbesar ternyata kuat arusnya mengecil. Jadi hukum Ohm bisa dibuktikan melalui media software PhET ini.

Materi hukum Kirchoff merupakan materi yang paling sulit dan paling sedikit dijawab benar oleh siswa. Ini diperkuat dengan hasil uji instrument yang menunjukkan bahwa materi hukum Kirchoff memiliki indeks kesukaran rata-rata 0,67 yang termasuk dalam klasifikasi soal sedang. Kesulitan para siswa pada materi tersebut adalah bagaimana memahami jumlah aljabar penurunan tegangan pada suatu jalur tertutup adalah nol. Siswa masih kesulitan dalam menentukan arah loop yang digunakan. Walaupun para siswa masih kesulitan dalam memahaminya, akan tetapi software PhET masih bisa dimanfaatkan untuk memudahkan siswa memahami hukum Kirchoff II tersebut misalnya dalam menentukan kuat arus yang mengalir pada loop 1 dan loop 2.

Secara keseluruhan dari analisis yang telah dilakukan didapatkan bahwa untuk ranah kognitif kelas eksperimen yang menggunakan media software PhET nilai rata-ratanya adalah 78,60 sedangkan untuk kelas kontrol nilai rata-ratanya adalah 69,39. Untuk ranah psikomotor, nilai rata-rata untuk kelas eksperimen adalah 78,10 dan untuk kelas kontrol 72,78. Berdasarkan uji statistik (uji-t) yang telah dilakukan, untuk ranah kognitif harga $t$ hitung $=4,05$ Harga ini lebih besar dari harga t table $=1,67$. Sedangkan untuk ranah psikomotor harga t hitung $=2,28$. Harga ini lebih besar dari harga t table $=1,67$.

Nilai $t_{\text {hitung }}>t_{\text {tabel }}$ menunjukkan adanya perbedaan yang signifikan dari rata-rata kedua kelas. Hal ini disebabkan adanya perbedaan perlakuan yang diberikan pada salah satu kelompok (kelompok eksperimen). Perlakuan yang dimaksudkan dalam penelitian ini adalah pembelajaran dengan menggunakan media software PhET pada kelas ekperimen dan pembelajaran tanpa media software PhET pada kelas kontrol. Melalui program software PhET ini, siswa tidak hanya mendengar tetapi juga melihat secara langsung tentang apa yang sedang dipelajari, misalnya pada materi listrik dinamis, bisa melihat bagaimana arah aliran muatan elektron. Dengan begitu siswa menjadi lebih mudah mengingat. Penggunaan software PhET ini akhirnya merangsang serta menantang rasa ingin tahu siswa yang kemudian dilanjutkan dengan melakukan suatu percobaan untuk membuktikan apa yang telah dipelajari sehingga siswa menjadi mengerti dan mengetahui serta menerima teori yang telah dipelajari karena sudah terbukti yang akhirnya meningkatkan prestasi belajar siswa.

Hal ini menunjukkan bahwa prestasi belajar siswa yang mengikuti pembelajaran dengan menggunakan media software PhET baik untuk ranah kognitif maupun ranah psikomotor lebih baik daripada siswa yang belajar tanpa menggunakan media software PhET. Dengan kata lain, media pembelajaran software PhET lebih efektif digunakan untuk meningkatkan prestasi belajar siswa daripada tanpa menggunakan media software PhET.

\section{KESIMPULAN \& SARAN}

\subsection{Kesimpulan}

Berdasarkan hasil penelitian dan pembahasan dapat ditarik kesimpulan sebagai berikut hipotesis $\mathrm{H}_{0}$ ditolak dan $\mathrm{H}_{a}$ diterima. Dengan demikian dapat disimpulkan bahwa pembelajaran dengan menggunakan media pembelajaran software PhET berpengaruh positif terhadap prestasi belajar fisika siswa kelas X SMA Negeri 8 Mataram.

\subsection{Saran}

Berdasarkan hasil penelitian, saran yang dapat diberikan oleh peneliti sebagai berikut. (1) Pada saat melaksanakan penelitian, kegiatan eksperimen riil harus dilakukan terlebih dahulu sebelum eksperimen virtual (simulasi PhET) agar siswa tahu bagaimana sesungguhnya kenyataan di lapangan cara menggunakan alat laboratorium, kemudian menggunakan media software PhET untuk mengkonstruk pengetahuan yang sudah didapat sebelumnya agar pemahaman siswa semakin baik. (3) Untuk peneliti lain, jika ingin melakukan penelitian yang serupa, disarankan menggunakan materi yang berbeda. Misalkan materi gelombang dan bunyi. Materi ini memiliki karakteristik konseptual yang menganalisis konsep dalam kehidupan sehari-hari sehingga memungkinkan mahasiswa mengaitkan konsep fisika dengan gejala yang dialaminya dalam kehidupan sehari-hari melalui kemampuan berpikirnya.

\section{DAFTAR PUSTAKA}

Arsyad, Azhar. 2011. Media Pembelajaran. Jakarta: PT. RajaGrafindo Persada.

Arends, R.I. 2012. Learning To Teach. New York: McGraw Hill Companies Inc.

Depdiknas. 2006. Permendiknas No.22 Kurikulum Fisika (Standar Isi). Jakarta: Depdiknas.

Finkelstein, N. 2006. High-Tech Tools for Teaching Physics: The Physics Education Technology Project. Merlot Journal of Online Learning and Teaching, 2(3): 110-121.

Flowers, L. 2011. Investigating The Effectiveness of Virtual Laboratories in a Undergraduate Biology Course. The Journal of Human Resource and Adult Learning, (Online), 7 (2): 1-13, (www.hraljournal.com) diakses 14 Juni 2013.

Karagoz, O dan Ozdener, N. 2010. Evaluation of The Usability of Different Virtual Lab Software Used In Physics Courses. Bulgarian Journal of Science and education Policy, (Online), 4(2): 216-235, (www.bjsep.org) diakses 13 Juni 2013.

Prihatiningtyas, S., dkk. 2013. Implementasi Simulasi PhET dan Kit Sederhana untuk Mengajarkan Keterampilan Psikomotor Mahasiswa pada Pokok Bahasan Alat Optik. Jurnal Pendidikan IPA Indonesia, 2(1): 18-22.

Pusporini, S., Ashadi, dan Sarwanto. 2012. Pembelajaran Kimia Berbasis Problem Solving 
Menggunakan Laboratorium Riil dan Virtual Ditinjau dari Gaya Belajar dan Kemampuan Berpikir Kritis Mahasiswa. Jurnal Inkuiri, 1(1): 34-43.

Sanaky, Hujair AH. 2009. Media Pembelajaran. Yogyakarta: Safiria Insania Press.

Sugiyono. 2010. Metode Penelitian Pendidikan. Bandung: Alfabeta.

Tuysuz, C. 2010. The Effect of the Virtual Laboratory on Students Achievement and Attitude in Chemistry. International Online Journal of Educational Sciences, (Online), 2(1): 37-53, (www.iojes.net) diakses 12 Juni 2013. 